\title{
Effect of cell compression on the water dynamics of a polymer electrolyte fuel cell using in-plane and through- plane in-operando neutron radiography
}

\author{
Nivedita Kulkarni ${ }^{1}$, Jason I. S. Cho ${ }^{1}$, Lara Rasha ${ }^{1}$, Rhodri E. Owen ${ }^{1}$, Yunsong Wu ${ }^{1}$, \\ Ralf Ziesche ${ }^{1}$, Jennifer Hack ${ }^{1}$, Toby Neville ${ }^{1}$, Mike Whiteley ${ }^{2}$, Nikolay Kardjilov ${ }^{3}$, \\ Henning Markötter ${ }^{3}$, Ingo Manke ${ }^{3}$, Paul R. Shearing ${ }^{1,2}$, Dan J. L. Brett ${ }^{1,2 *}$
}

\footnotetext{
${ }^{1}$ Electrochemical Innovation Lab, Department of Chemical Engineering, UCL, London, UK, WC1E 7JE

${ }^{2}$ Advanced Propulsion Lab, UCLEast, London, UK, WC1E 7JE

${ }^{3}$ Helmholtz-Zentrum Berlin (HZB), Hahn-Meiitner-Platz 1,14109 Berlin, Germany
}
* Author to whom correspondence should be addressed
Tel.: +44 (0)207679 3310
Web: www.ucl.ac.uk/electrochemical-innovation-lab
Email: d.brett@ucl.ac.uk

\begin{abstract}
Water dynamics in the membrane electrode assembly (MEA) and flow channels of polymer electrolyte fuel cells (PEFCs) is governed by the complex interplay of many physical and operational factors. The chemical nature and structure of the gas diffusion layer (GDL) plays a large part in this and is affected by the extent to which is mechanically compressed. Here, $\mathrm{X}$-ray computed tomography shows the effect of cell compression on the MEA, and how it differs under the land and channel regions. Multi-orientation neutron radiography reveals the effect of compression on the way in which water accumulates and is transported between land and channel and between cathode and anode. By performing neutron imaging in both the inplane and through-plane directions it is possible to determine what constitutes a given 'thickness' of water mapped across the extent of an MEA. Changing MEA compression from $25 \%$ to $35 \%$ has a significant effect on water distribution and dynamics in operational cells. The effect of compression on performance is most marked in the mass transport region and there are consequences for liquid accumulation in channels and back-diffusion of water from the cathode to the anode.
\end{abstract}

Keywords: Water management; neutron imaging; assembly pressure; X-ray computed tomography; water retention; back-diffusion. 


\section{Introduction}

Polymer electrolyte fuel cells (PEFCs) are a promising alternative to traditional power sources due to their high efficiency, low operating temperature, and high power density. While the technology continues to advance, there still exists scope for performance and durability improvements. One of the best ways to make these improvements is by having a detailed understanding of how these devices operate in operando; this insight can then inform improved engineering design, assembly, materials selection and operating conditions $[1,2]$.

At the core of the PEFC is the membrane electrode assembly (MEA) which consists of a thin electrolyte membrane with electro-catalyst and fibrous gas diffusion layers (GDL) on either side. This assembly is sandwiched between flow-fields that serves numerous functions, including water removal, current collection and providing mechanical support to the system [3-7]. The PEFC performance is determined by various design and operating parameters, such as flow-field design, reactant flow-rates, temperature, pressure and humidity $[6,8-$ 12]. The effects of operating parameters on the fuel cell performance are typically tested during real cell or stack testing. However, with the advancement in computational capability, various multi-phase fuel cell models have been developed that show the effect of operating parameters on fuel cell performance [13-19]. Though the modelling efforts are being made to optimise the fuel cell design for future PEFCs $[20,21]$ and understand in-situ processes, such as water transport at the porous domains [7], the input parameters required for the comprehensive model can only be obtained through experiments.

Practically, the way in which the cell/stack is brought into mechanical compression also has an important effect on performance is it has an effect on the structure of components (how much they are compressed/deformed). Adequate cell compression, typically between 20 to $40 \%$, is also required for good sealing and electrical contact between cell components $[9,22]$. The compression percentage represents the amount by which the MEA has been compressed with respect to its original thickness. Various compression methods have been utilised in the past, such as hydraulic and pneumatic presses [8], compression springs [23], clamping plates or compression torque [24]. However, these methods are designed for pressure-based compressions and the extent of dimensional change of the MEA cannot be directly measured or controlled. The degree of cell compression can also be controlled by varying the thickness of 'incompressible' sealing gaskets $[25,26]$. This method ensures the cell is evenly compressed and leak-free. 
Water transport in porous domains of the fuel cell, such as the GDL, MPL and CL, is one of the key parameters that impact water management and subsequently fuel cell performance $[27,28]$. These porous layers are structurally affected when subjected to cell compression.

During cell compression, regions of the GDL directly underneath the flow-field lands are subjected to the compressive load. This leads to constriction of the GDL in these regions and the protrusion of carbon fibres onto the gas channels ('tenting'), creating distinct 'under the land' and 'under the channel' zones. Non-uniform and excess compression can lead to irreversible morphological changes which can significantly influence the mass transport across the porous medium [29-33]. The X-ray computed tomography (CT) study by Kulkarni et al. revealed that the compression leads to the effective properties of the porous medium such as porosity, tortuosity, permeability, being different under the land and the channel region [34]. The GDL porosity under the channel was $20 \%$ higher than under the land region when measured at $40 \%$ compression. This change in porosity affects the permeability and gas diffusivity. Whilst increased compression reduces porosity, permeability and gas diffusivity under the land, GDL 'tenting' typically increases these properties under the channel, inducing an uneven distribution of effective properties that affect the cell performance.

An X-ray CT compression study by Atkinson et al. showed that an increase in compression to $41 \%$ resulted in a reduction in the average pore size radius by $24 \mu \mathrm{m}$ and lowered the GDL porosity, for SGL 29BC commercial carbon paper GDE [35]. Change in morphological properties of the cell marginally affected the cell performance at lower current densities where water generation and retention was insignificant. However, the cell performance was reduced by $23 \%$ with an increase in cell compression from $14 \%$ to $41 \%$ measured at the mass transport region $(0.4 \mathrm{~V})$. Synchrotron X-ray imaging study of the aged GDL by Ince et al. showed that the increase in the cell compression results in the increased tendency of the in-plane water transport that may lead a performance degradation in the operating fuel cell [36]. Electrochemical impedance spectroscopy studies by Mason et al. [37] and Nitta et al. [38] showed that the higher cell compression improves GDL conductivity due to increased fibre-tofibre contacts and reduced contact resistance at both the bipolar plate-GDL interface and GDL-catalyst layer interface, thereby improving the current collection. Cell compression leads to several conflicting effects on cell performance, the role of water is one such factor, which is not fully understood. It is therefore desirable to have a comprehensive understanding of where and how water is distributed in a fuel cell as a function of mechanical compression so that optimum conditions can be identified. 
High-resolution neutron imaging is a particularly powerful technique for probing water in fuel cells. The neutron beam is strongly attenuated by hydrogen-containing compounds such as water while being relatively transparent to heavier atoms that constitute the remainder of fuel cell components, (bipolar plates, gaskets, etc.). These properties make the technique particularly versatile for visualising water dynamics across a fuel cell [39-47]. While this technique can resolve water at higher resolution, the key limitation is a smaller field-of-view [48-52]. Hence, a careful balance between resolution, exposure time and the field-of-view or size of the active area has to be met to generate adequate data from the neutron imaging.

Neutron imaging can be applied in the in-plane orientation, where the MEA is parallel to the neutron beam or in the through-plane orientation, where the MEA is perpendicular to the beam. The in-plane radiographs of operating cells provide information regarding the water content in different layers of the MEA but do not give an indication of where the water is distributed spatially across the entire fuel cell active area [53-55]. The through-plane radiographs provide water retention profile along the channel length, but cannot identify in which layer of the cell the water resides. [56-58]. The relationship between cell compression and the fuel cell performance was evaluated by Wu et al. using through-plane neutron imaging, showing an overall increase in water content in the channel with increasing compressions; however, no information was provided regarding the effect of cell compression on the water accumulation in the MEA layers [59].

In this work, a combined study of X-ray CT and multi-orientation in-operando neutron radiography, both in the in-plane and the through-plane orientation is used to investigate the effects of cell compression on the water dynamics of the fuel cell. This allows for a detailed analysis of the effect of compression on membrane hydration, water distribution under the land and across the channel domains, and back-diffusion of water across the membrane, from the cathode to the anode domain. The neutron imaging performed in both the in-plane and through-plain allows determining what constitutes a given 'thickness' of water mapped across the extent of an MEA.

\section{Experimental}

\subsection{Cell design and compression}

A closed-cathode PEFC with an active area of $6.3 \mathrm{~cm}^{2}$ was used in the study. The cell comprised of aluminium end-plates, current collectors and flow-fields, as shown in Figure 1(a). The end-plates, current collectors and flow-fields were gold-coated to increase corrosion 
resistance and decrease electrical resistance. PTFE gasket sheets were used to seal the perimeter of the MEA on either side of the membrane. Tygaflor gasket sheet (70 $\mu \mathrm{m}$ thickness) was used for electrical insulation between the current collector and the end-plate. VITON rubber O-rings were used to provide a gas/liquid seal at the interface between current collectors and flow-fields. A parallel flow-field arrangement was used to give a clear visualisation of water emerging into the channel. This is not possible with a serpentine configuration where meanders overlap in the in-plane direction. The bifurcating reactant delivery channels were designed on the back of the flow-field to ensure uniform gas distribution across individual parallel gas channels, as shown in Figure 1(c) $[57,60,61]$.
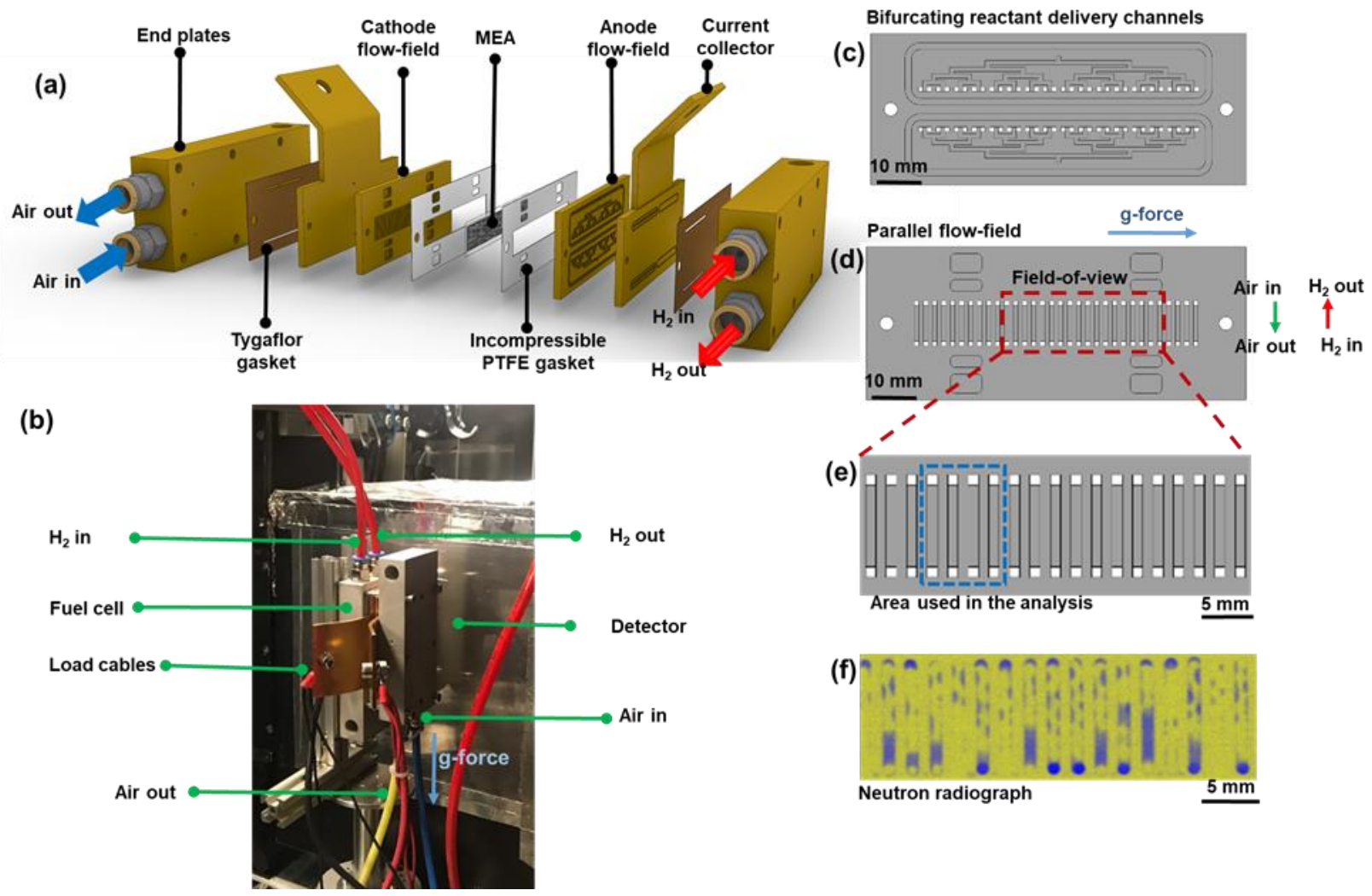

Figure 1 (a) Exploded view of the fuel cell showing individual components, (b) neutron radiography set-up at CONARD to generate in-operando radiographs in the in-plane and the through-plane orientation, The cell was held in the vertical orientation (c) bifurcating reactant delivery channels on the back-side of the flow-field to ensure uniform reactant delivery to individual parallel gas channels, (d) the parallel gas channels where the highlighted region in red indicates the field-of-view used in this study, (e) highlighted region in blue shows the area used in the analysis. The particular area of interest includes four channels in the centre of the fuel cell. ( $f$ ) Generated radiograph in the through-plane orientation masked with yellow and blue colour, yellow representing the dry region and blue representing the higher water content.

The MEAs were assembled from commercial carbon fibre GDEs with a platinum catalyst loading of $0.4 \mathrm{mg} \mathrm{cm}^{-2}$ (HyPlat, South Africa) and a $50 \mu \mathrm{m}$ thick ionomer membrane (GORE, USA). The MEAs were hot-pressed at $130^{\circ} \mathrm{C}$ for 3 minutes at 400 psi applied pressure (Carver 4122CE, USA). The hot pressing conditions were chosen based on previous work [62]. 
PTFE sheets of $50 \mu \mathrm{m}$ and $75 \mu \mathrm{m}$ were laser-cut to the cell's dimension. Multiple sheets stacked together were used to achieve the required degree of compression. The GDL thickness and details of the gaskets used are presented in Table 1. The particular compression levels were chosen to evaluate the typical range of cell compression that assures good sealing and the performance of the fuel cell. The initial torque of $1.5 \mathrm{Nm}$ was used to tighten the bolts. A micrometre (RS Pro, accuracy $\pm 5 \mu \mathrm{m}$ ) was used to reassure the changes in GDL thickness with compression. A laboratory X-ray CT system, ZEISS Xradia 520 Versa (Carl Zeiss, USA) was used to examine the structural behaviour of the MEA under compression. (Figure 2(b)). A source voltage of $80 \mathrm{kV}$ and a field-of-view of $3 \times 3 \mathrm{~mm}^{2}$ were used for the sample, giving a voxel size of $1.6 \mu \mathrm{m}$. A bright phase observed in the middle region of the ortho-slice is Nafion membrane and Pt catalyst layer, and the surrounding lighter phase is the GDL coated with the microporous layer. With an increase in cell compression, the fibre density of the GDL has increased in the region under the land, causing the loss of porosity, as presented in Table 2. However, the region under the channel undergoes 'tenting'. This results in the non-uniform structural and effective mass transport properties in the fuel cell.

Table 1 GDL thickness achieved using PTFE gaskets

\begin{tabular}{|l|l|l|}
\hline Gasket thickness $(\mu \mathrm{m})$ & GDL thickness $(\mu \mathrm{m})$ & Cell compression $(\%)$ \\
\hline & 238 & $0 \%$ \\
\hline $50+50+75$ & 175 & $\sim 25 \%$ \\
\hline $50+50+50$ & 150 & $\sim 35 \%$ \\
\hline
\end{tabular}




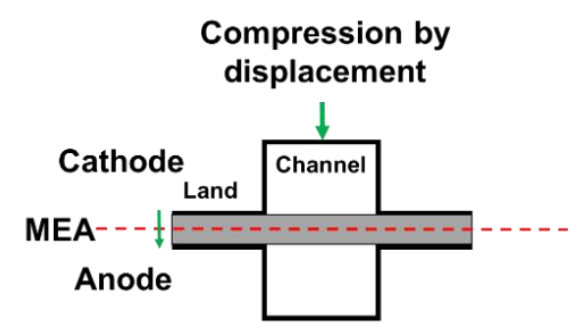

(a)
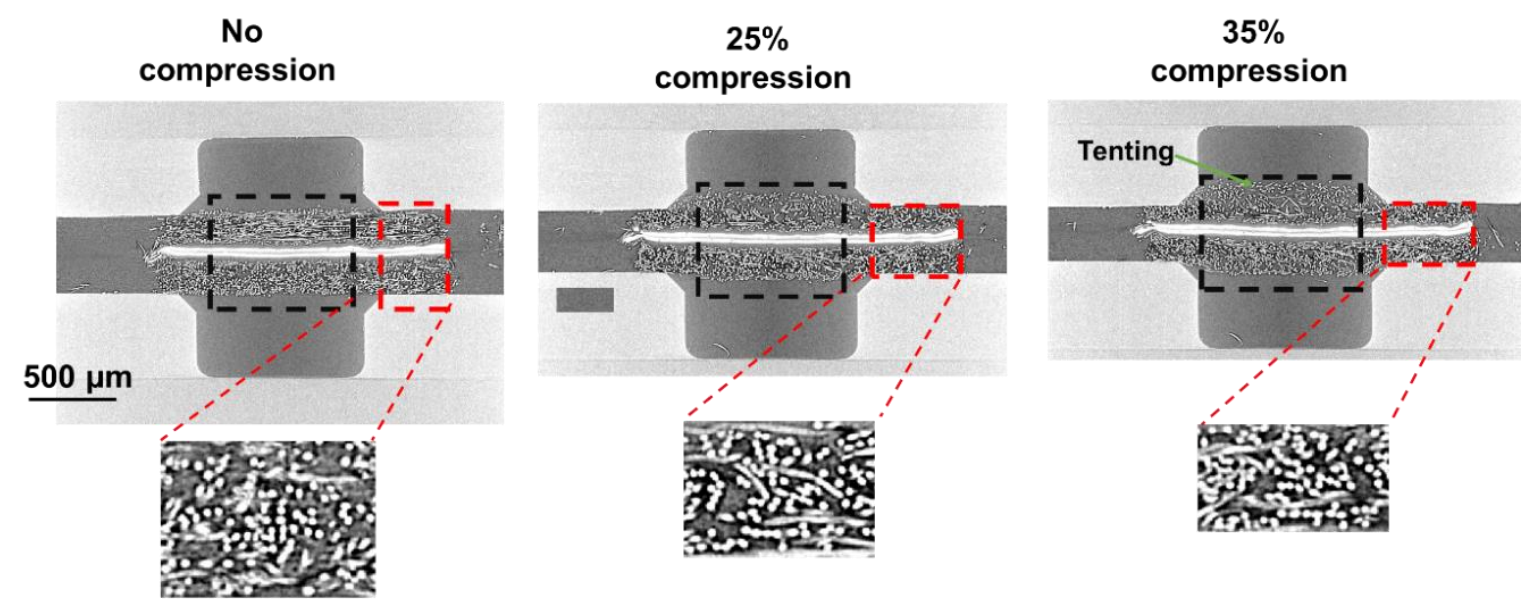

(b)

Figure 2 (a) schematic of the in-plane view of the flow-field channel, (b) X-ray CT images of the prepared MEA showing the effect of compression on the MEA measured before the compression, at $25 \%$ and at $35 \%$ compression. Red highlighted area shows the domain under the land, the black highlighted area shows domain under the channel. The detailed view of the region under the land depicts that the porosity reduces with an increase in cell compression

Table 2 Porosity values derived from the X-ray CT analysis

\begin{tabular}{|c|c|c|}
\hline Compression & $\begin{array}{c}\text { Porosity under the } \\
\text { land }\end{array}$ & $\begin{array}{c}\text { Porosity under the } \\
\text { channel }\end{array}$ \\
\hline $0 \%$ & 0.75 & 0.75 \\
\hline $25 \%$ & 0.65 & 0.78 \\
\hline $35 \%$ & 0.56 & 0.79 \\
\hline
\end{tabular}

\subsection{Experimental procedure}

An in-house fuel cell test rig and control software based on LabVIEW (National Instruments, USA) was used to operate the PEFC. The experimental data were acquired with a data acquisition card (DAQ card, USB 6363, - National Instruments, USA). The cell was operated under dry gas conditions to evaluate the water dynamics in isolation from the water present in 
a humidified reactant stream. Dry reactant delivery allows evaluation of back-diffusion of the water during operation. The cell was tested under ambient temperature conditions.

The cell was operated at a fixed flow condition where both anode and cathode flow-rates were set at $0.5 \mathrm{~L} \mathrm{~min}^{-1}$ during neutron imaging. The cell was flushed with high flow rates, $1 \mathrm{~L} \mathrm{~min}^{-1}$, before changing the operating conditions, ensuring the removal of accumulated water from the previous experiment. The reactant gas flow was controlled using digital mass flow controllers (Bronkhorst, UK). The current was drawn from the fuel cell using a DC electronic load (PLZ664WA, Kikusui).

Table 3 Cell conditioning parameters before the neutron radiography experiments

\begin{tabular}{|l|l|}
\hline Operation & Conditions \\
\hline Polarisation range & OCV to $0.4 \mathrm{~V}$ \\
\hline Cell conditioning & $10 \mathrm{~min}$ \\
\hline $\begin{array}{l}\text { Hold time per current increment } \\
\left(0.1 \mathrm{~A} \mathrm{~cm}^{-2}\right)\end{array}$ & $1 \mathrm{~min}$ \\
\hline Flushing time & 5 mins \\
\hline
\end{tabular}

Separate experiments were carried out for the in-plane and the through-plane orientation for each compression. The current load was increased from 0.01 to $1.1 \mathrm{~A} \mathrm{~cm}^{-2}$ in steps of $0.1 \mathrm{~A}$ $\mathrm{cm}^{-2}$ until the voltage reached $0.4 \mathrm{~V}$. Three fast polarisation curves were generated before holding the current at $0.1,0.6$, and $1 \mathrm{~A} \mathrm{~cm}^{-2}$ for $300 \mathrm{~s}$ each. The same current sweep procedure was repeated after each change in the orientation and compression. The details of the fastpolarisation curve are as presented in Table 3.

\subsection{Neutron radiography}

Neutron radiographs were generated at the low energetic (cold) neutron radiography (CONRAD) beamline facility at Helmholtz-Zentrum Berlin (HZB). The neutron radiography setup is shown in Figure 1(b). The cold neutron facility provides high attenuation contrast for thin hydrogenous based (hydrogen-containing) layers of the fuel cell, making it the best option to generate in-operando radiographs of the fuel cell [48]. The beam formed by a pinhole of 3 $\mathrm{cm}$ at a distance of $5 \mathrm{~m}$ is transmitted through the PEFC. The detector consisted of a digital camera with sCMOS chip (Andor Neo $2560 \times 2160$ pixel) facing a $200 \mu \mathrm{m}$ scintillator screen. The cell mounted on a fixture was placed on a rotating table, allowing radiographs in both the in-plane and through-plane orientation. An imaging field-of-view of $40 \times 34 \mathrm{~mm}^{2}$ with $15.2 \mu \mathrm{m}$ pixel $^{-1}$ resolution was achieved using the imaging set-up previously developed by Kardjilov et 
al. [48]. In-plane imaging at a resolution of $15.2 \mu \mathrm{m} \mathrm{pixel}^{-1}$ cannot unequivocally separate the GORE membrane from the catalyst layers and are thus grouped and referred to as the 'membrane electrode assembly (MEA). Each image was taken with an exposure time of $5 \mathrm{~s}$. The liquid water image was generated by normalising the wet image to the dry fuel cell image taken at the beginning of each experiment and any non-uniformity in the beam-intensity was corrected with an open-beam image. The quantification of the water thickness from neutron images was performed using the Beer-Lambert law:

$$
\delta_{\text {water }}=\frac{-\ln \left(\frac{I}{I_{o}}\right)}{\epsilon_{\text {water }}}
$$

Where $\delta_{\text {water }}$ refers to the liquid water thickness in $\mathrm{cm}, \epsilon_{\text {water }}$ is the attenuation coefficient of the neutron in liquid water, measured in the given setup as $5.3 \mathrm{~cm}^{-1}, I_{0}$ is the intensity of the dry image taken before the cell operation starts, and $I$ is the intensity of the wet image taken during the cell operation. The radiographs presented were originally grey-scale images which were masked with a yellow-to-blue 'parula' colour-map, blue representing the presence of higher levels of water.

\section{Results and discussion}

\subsection{Effect of compression on polarisation performance}

Figure 3 shows the effect of cell compression on the polarisation and the power density curves. A polarisation curve can notionally be divided into three regions, the activation region, $(V<0.8$ $\mathrm{V})$, the Ohmic region $(0.5 \mathrm{~V}<\mathrm{V}<0.8 \mathrm{~V})$, and the mass transport region $(V<0.5 \mathrm{~V})$. The activation kinetics are primarily reliant on catalyst properties and particularly sensitive to operational temperature. Therefore, the compression did not show any notable difference in the activation performance. With increases in current density, the effect of compression on the cell performance was apparent. [9,59,63]. In the Ohmic region, the $25 \%$ compressed cell showed better performance. At $j=0.6 \mathrm{~A} \mathrm{~cm}^{-2}$, the cell performance of the $35 \%$ compressed cell was reduced by $4 \%$ compared with the $25 \%$ cell compression. In the mass transport region $\left(j=1 \mathrm{~A} \mathrm{~cm}^{-2}\right), 25 \%$ compression showed $11 \%$ increase in performance. The maximum power density achieved at $25 \%$ compression was $0.49 \mathrm{~W} \mathrm{~cm}^{-2}$; whereas, the maximum power density reached at $35 \%$ compression was $0.47 \mathrm{~W} \mathrm{~cm}^{-2}$. 


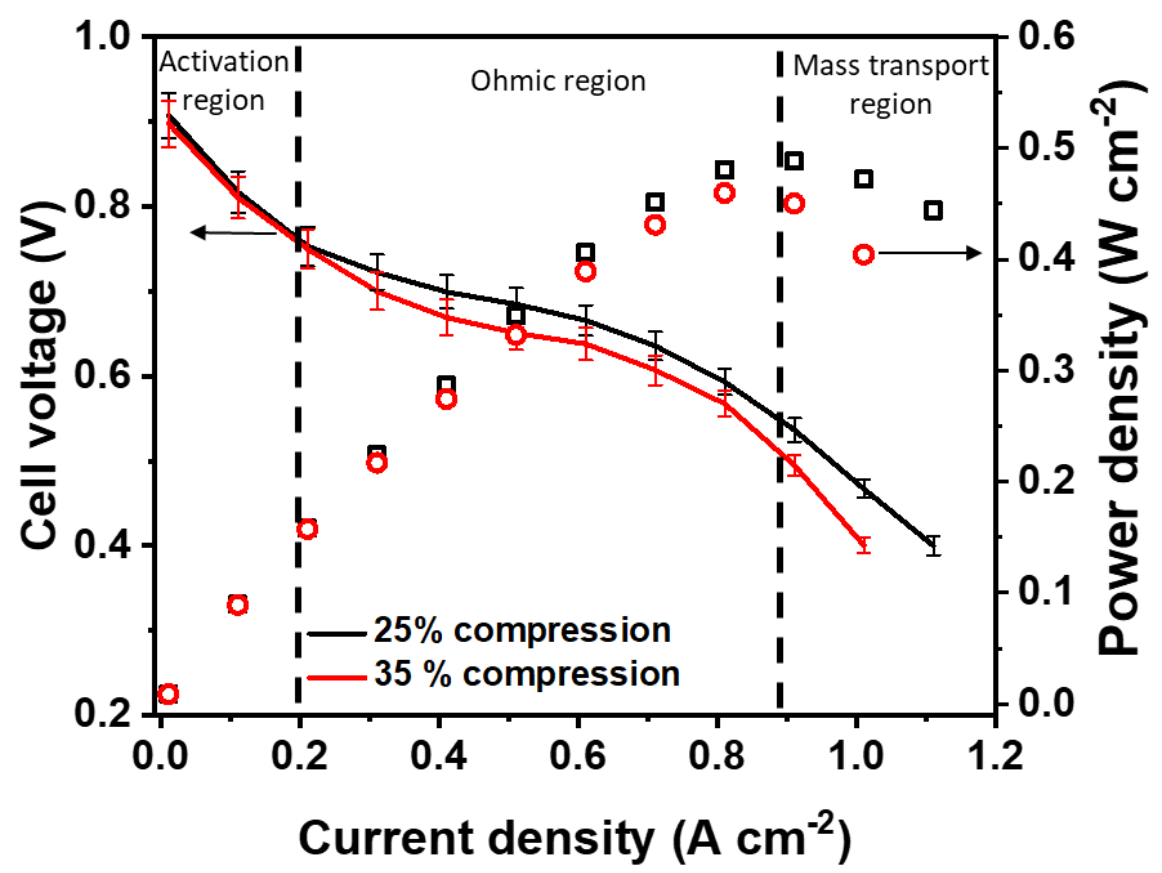

Figure 3 Comparison of polarization performance with a change in compression. Error bars indicate the difference between three repeat runs; Solid lines (-) are cell voltage, hollow shapes ( $\square$ ) are power density.

In the present case, the porosity under the land region lowered by $13 \%$ and $25 \%$ with an increase in compression to $25 \%$ and $35 \%$, respectively. Lowered GDL porosity under the land region lowers the contact resistance [34]. The electrochemical impedance spectroscopy (EIS) study by Mason et al. shows that the increase in cell compression to $25 \%$ (i.e. dimensional change of $60 \mu \mathrm{m}$ ) lowered the Ohmic resistance from $29 \mathrm{~m} \Omega \mathrm{cm}^{2}$ (at no compression) to 14 $\mathrm{m} \Omega \mathrm{cm}^{2}$. Further, an increase in the compression to $35 \%$ (i.e. dimensional change of $83 \mu \mathrm{m}$ ) lowered the Ohmic resistance to $10 \mathrm{~m} \Omega \mathrm{cm}^{2}$ [37]. Therefore, though the increase in cell compression is an effective method for reducing Ohmic losses associated with the contact resistance [9], this leads to a loss of GDL porosity under the land region (Figure 2) which affects the water management in the Ohmic region.

This strongly suggests that an increase in cell compression increases the mass transport dominance in the Ohmic and promotes early mass transport due to the limitations in water management. Hence, to maximise the performance, an optimal compression needs to be determined, which is a trade-off between electrical and mass transport factors. 


\subsection{Neutron radiographs at fixed flow-rate}

The polarisation data can be coupled with the neutron imaging that provides detailed and instantaneous information regarding the water dynamics in the fuel cell, which can obtain a better picture of an operating fuel cell.

\subsubsection{Activation region}

At open circuit voltage, no water is produced electrochemically. Hence, the cell is in dry condition. With an increase in current density, water is produced across the active area. Figure 4 shows the radiographs taken over $300 \mathrm{~s}$ in separate in-plane and through-plane experiments, with all the operating conditions identical.

(a)

\section{In-plane orientation}

$$
\text { channel }
$$

$25 \%$ compression
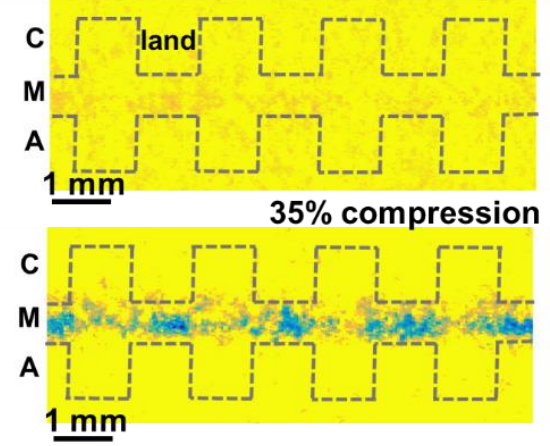

(b)

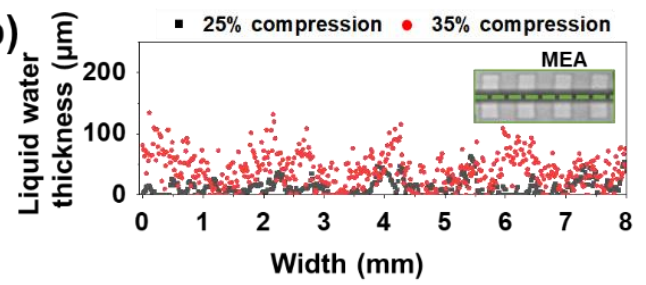

(c) Through-plane orientation $25 \%$ compression $35 \%$ compression
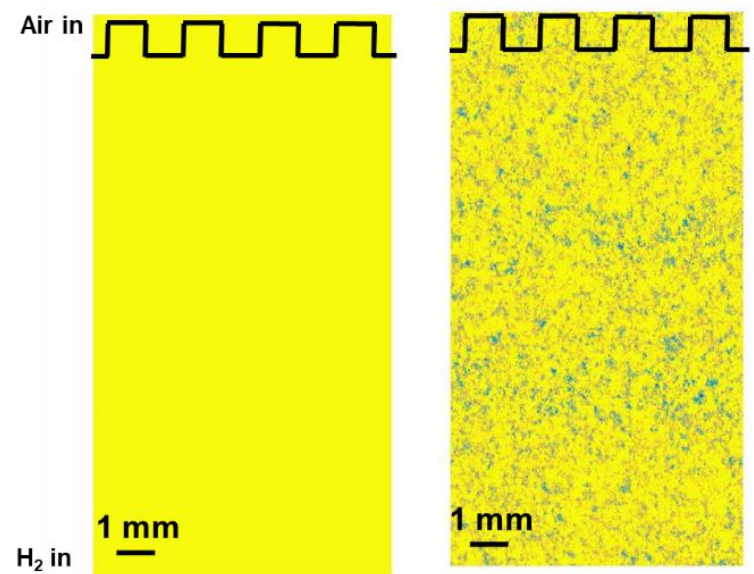

Liquid water thickness $(\mu \mathrm{m})$

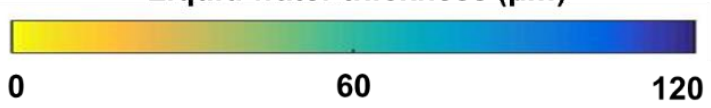

Figure 4 Effect of compression on the water distribution in the activation region, $j=0.1 \mathrm{~A} \mathrm{~cm}^{-2}$ when the flow of the reactants was fixed to $0.5 \mathrm{~L} \mathrm{~min}^{-1}$, equating to $>10$ air stoichiometry. (a) in-plane radiographs measured at $t=$ $300 \mathrm{~s}$, ' $\mathrm{C}$ ' is the cathode flow-channels, ' $\mathrm{M}$ ' is MEA (GDLs+CLs+membrane) and ' $A$ ' is an anode flow-channels, Grey dashed line showing the flow-field outline is included as a guide to the eye (b) liquid water thickness profile in the in-plane orientation measured at the membrane/CL showing the effect of channel/land geometry on the

water retention. Green dashed line at membrane/CL shows the schematic location where the liquid water thickness was measured, and (c) through-plane radiographs measured at $t=300 \mathrm{~s}$. (a) and (c) shares the same colour bar.

The in-plane radiographs for both compressions are shown in Figure 4(a). At $0.1 \mathrm{~A} \mathrm{~cm}^{-2}$, the cell at $25 \%$ compression appeared to be almost dry (average $\delta_{\text {water-membrane }}<13 \mu \mathrm{m}$ ). Although the same amount of water was being generated at a given current density, at $35 \%$ cell compression the presence of water was seen in the MEA (in Figure 4(a) - blue region) with 
average water thickness increased to $42 \mu \mathrm{m}$. Moreover, the tendency to accumulate water under the land is evident at $35 \%$ cell compression with distinctive 'peak' and 'valley' profiles in the CL-membrane that correspond to the land and channel regions, respectively (Figure 4(b)). This suggests that the compression affects the condensation of liquid water under the land region; whereas, water evaporation is promoted under the channels [42,64].

The through-plane radiographs are shown in Figure 4(c). No significant water signal was observed for the $25 \%$ compression, with a relatively uniform water distribution for the $35 \%$ compression with no clear demarcation between land and channel zones. This is clearly in contrast to the in-plane representation. This could be due to greater signal-to-noise is achieved for the in-plane analysis as the neutron probe integrates a much larger sample through the length of a channel. The collective analysis of the voltage profile and radiographs at the activation region strongly suggest that the compression has a marginal effect on voltage performance, though the water accumulation in the cell became noticeable with an increase in the compression. However, the stable performance indicates the balance between water generation, capillary transport, forced convection and accumulation.

\subsubsection{Ohmic region}

In the 'notional' Ohmic region, an increase in the current density elevates water production. As the name suggests, the voltage loss in the Ohmic region is typically considered to be dominated by ionic and electronic losses. However, it has been shown that an increase in cell compression increases the mass transport resistance in the Ohmic region which leads to the accumulation of liquid water in the MEA, amplifying the voltage loss $[9,65]$. The radiographs presented in Figure 5 compare the galvanostatic cell performances at both compressions in the Ohmic region $\left(j=0.6 \mathrm{~A} \mathrm{~cm}^{-2}\right)$.

The in-plane radiographs for Ohmic operation for each cell compression are shown in Figure 5 (a) obtained at $t=300 \mathrm{~s}$. In general, irrespective of the compression, the overall water content has increased with the current density showing the presence of the water at $25 \%$ cell compression (blue region in the MEA). The average water thickness at $25 \%$ compression was $225 \mu \mathrm{m}$, with a standard deviation of $101 \mu \mathrm{m}$, while at $35 \%$ compression, the average water thickness increased to $291 \mu \mathrm{m}$ with a standard deviation of $101 \mu \mathrm{m}$ (Figure 5(b)). The comparative analysis of water accumulation implied that the increase in the cell compression to $35 \%$ increases the water accumulation by $27 \%$, with clear 'peaks' and 'valleys' that 
correspond to the land and channel regions, respectively. Moreover, almost constant standard deviation suggests that the probability of the water accumulation at a particular location was the same for both the compressions, while the water content differed. Water transport in the GDL is governed by capillary action. Lowered GDL pore diameter under the land region alters the capillary pressure, which further promotes the water vapour condensation under the land, increasing water retention in the GDL under the land region. [1,40,42,66,67]. Therefore, increase in compression to $35 \%$ results in lowering the porosity under the land region, as shown in Figure 2, and increasing the local water thickness maxima to $580 \mu \mathrm{m}$ compared to $500 \mu \mathrm{m}$ at $25 \%$ compression. The non-uniform liquid water distribution in the MEA promotes non-uniform current generation when operated in a galvanostatic mode $[68,69]$. Non-uniform current generation leads to the local hot spots and alters the durability of the cell in the long run.

The water profile shown in the through-plane radiographs indicates the presence of water in the form of droplets spread across the active area (Figure 5(c)). Though larger water droplets were seen at $35 \%$ compression, neither water accumulation in the channels or the dry-out areas were observed in the Ohmic region. Therefore, whilst all other operating parameters were constant, the change in liquid water retention and voltage decay at $j=0.6 \mathrm{~A} \mathrm{~cm}^{-2}$ was due to cell compression. The increase in cell compression leads to a noticeable variation in water accumulation and water retention under the land region. The dry cell operation at a high flow rate (air stoichiometry 7.5) resulted in the removal of the product water through evaporation under the channel region, while providing adequate membrane hydration. The increase in compression lowers the electrical contact resistance and increases water accumulation under the land. Accumulated water hinders the reactant transport to the active layers, increasing reactant transport resistance [9]. As the reactant transport resistance is higher than the contact resistance, an increase in compression promotes mass transport in the 'Ohmic' region. 


\section{(a) In-plane orientation}
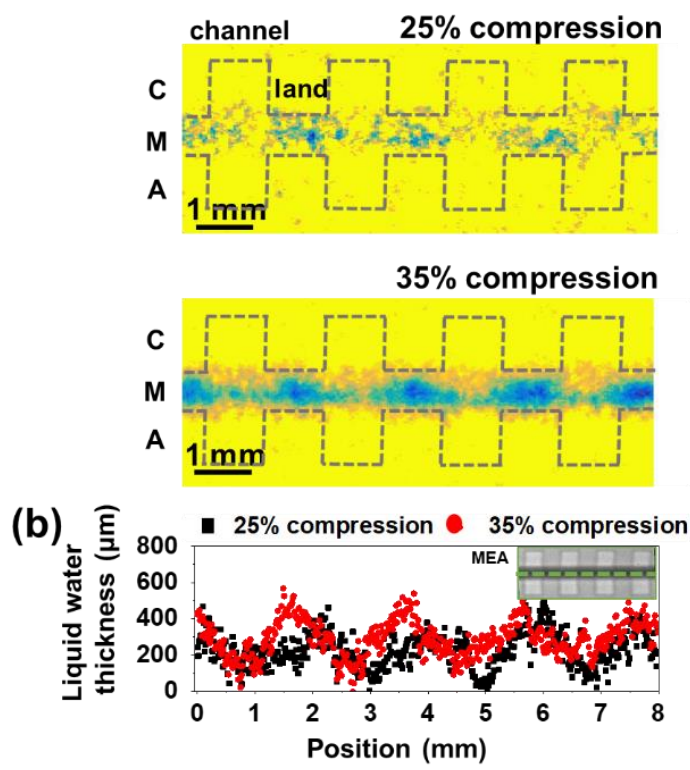

\section{(c) Through-plane orientation}
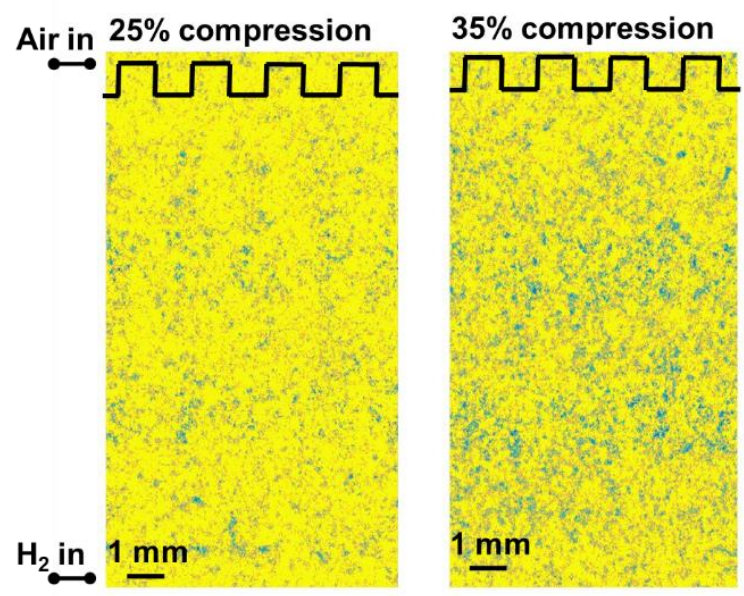

Liquid water thickness $(\mu \mathrm{m})$

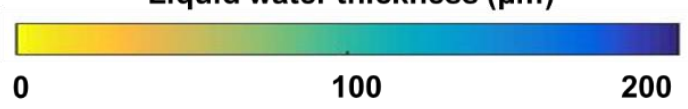

Figure 5 Effect of compression on the water distribution in the Ohmic region, $j=0.6 \mathrm{~A} \mathrm{~cm}^{-2}((\mathrm{a})$ in-plane radiographs at $t=300 \mathrm{~s}$, ' $C$ ' is the cathode flow-channels, 'M' is MEA (GDLs+CLs+membrane) and ' $A$ ' is an anode flow-channels, Grey dashed line showing the flow-field outline is included as a guide to the eye (b) liquid

water thickness profile in the in-plane orientation measured at the membrane/CL showing the effect of channel/land geometry on the water retention. Green dashed line at membrane/CL shows the schematic location, where the liquid water thickness was measured, and (c) through-plane radiographs at $t=300 \mathrm{~s}$. (a) and (c) shares the same colour bar.

\subsubsection{Mass transport region}

Figure 6 displays the liquid water profile at each cell compression, operated in the mass transport region $\left(j=1 \mathrm{~A} \mathrm{~cm}^{-2}\right)$ with the flow rate fixed at $0.5 \mathrm{~L} \mathrm{~min}^{-1}$ equating to air stoichiometry of $\sim 4.44$. The in-plane radiographs shown in Figure 6(a) reveal the combined, yet distinct, effect that land/channel geometries and cell compression have on water accumulation. In general, an increase in compression resulted in the increased propensity of water accumulation in the cell during the mass transport operation (on comparison with the Ohmic operation). These results are in agreement with previous studies [40,68,70,71]. The discernible feature of mass transport operation was the back-diffusion of water, observed at both compressions. The water vapour condenses under the land region and saturates the GDL. The liquid water starts 'bulging' into the channel, forming water droplets, while some water back-diffuses to the anode domain. This behaviour can be clearly seen in the in-plane radiographs. The behaviour agrees with the previously reported experimental and modelling studies $[53,65,72-75]$. The hydrophilic contact angle observed between water droplets and 
the channel wall $\left(\theta=84^{\circ}\right.$, highlighted by the red arrow in Figure 6(c)), was due to the gold coating on the aluminium plate $[40,76]$.

The water content in the MEA depicted in Figure 6(b) shows increased water thickness with flooded 'peaks' and relatively dry 'valleys'. This confirms non-uniform accumulation and retention of the liquid water. The average water thickness at $25 \%$ compression was $350 \mu \mathrm{m}$ with a standard deviation of $124 \mu \mathrm{m}$. Increase in compression resulted in a $7 \%$ increase in average water thickness, reaching $373 \mu \mathrm{m}$ with a standard deviation of $104 \mu \mathrm{m}$.

(a) In-plane orientation

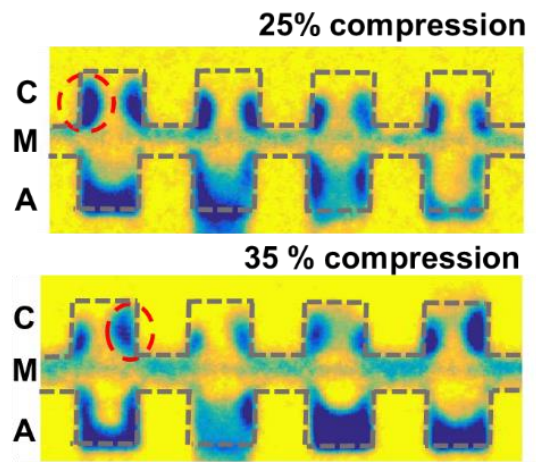

(b)

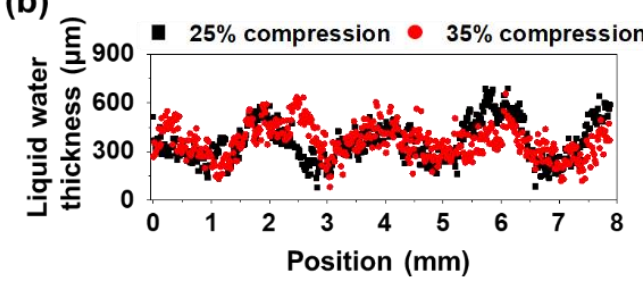

(c) Through-plane orientation

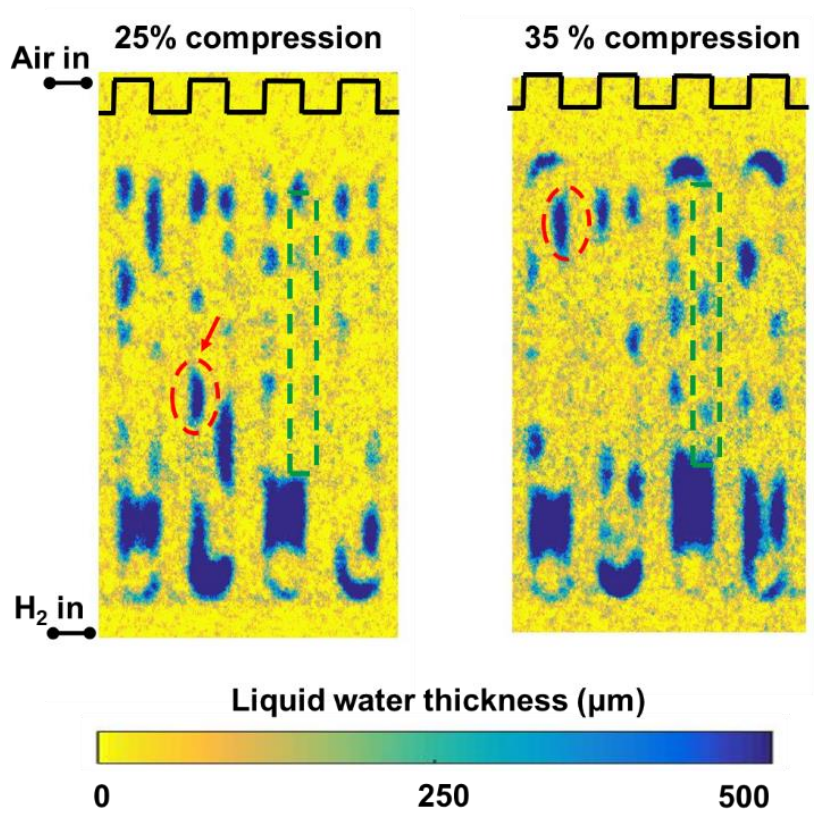

Figure 6 Effect of compression on the water distribution in the mass transport region, $j=1 \mathrm{~A} \mathrm{~cm}^{-2}$ (a) in-plane radiographs measured at $t=300 \mathrm{~s}$, ' $C$ ' is the cathode flow-channels, ' $\mathrm{M}$ ' is MEA (GDLs+CLs+membrane) and ' $\mathrm{A}$ ' is an anode flow-channels, Grey dashed line showing the flow-field outline is included as a guide to the eye (b) liquid water thickness profile in the in-plane orientation measured at the membrane/CL showing the effect of channel/land geometry on the water retention. (c) through-plane radiographs measured at $t=300 \mathrm{~s}$. (a) and (c) shares the same colour bar

The through-plane radiographs in Figure 6(c) provides key information regarding the effect of compression on water retention, water spread, and droplet/slug formations. In general, the through-plane radiographs in the mass transport region revealed well-defined channel/land profiles, highlighting the accumulation of liquid water in the channel. This result agrees with previously published studies [44,57-59,77].

The through-plane hydrographs revealed that the overall water content in the channel has increased with compression in the form of three main water retention profiles, namely, water droplets, slugs, and films. The hydrophilic nature of the channel walls leads to the formation 
of water droplets and further develops into slugs [78,79]. Large and elongated water droplets (length $>1000 \mu \mathrm{m}$ ) highlighted in 'red', were observed on the channel wall, while 'isolated' droplets were observed across the active area of the cell.

The present cell was operated in counter-flow mode, but results will be a function of the flowfield design. The net flux of water between electrodes can vary locally depending on the flow arrangement and local relative humidity at the anode and cathode. For example, in counterflow with dry anode feed, the net flow of water from cathode to anode is likely, with backdiffusion being dominant. Whereas, at the exit of the anode, where the stream has become fully humidified, net water flux could be in the opposite direction due to electro-osmotic drag outweighing back-diffusion as a result of lower hydraulic gradient from cathode to anode. As the present cell was operated at low temperature and relatively high feed gas velocity, the effect of relative humidity gradients along channels is minimised $[14,80]$. The increased saturation towards the cathode channel outlet reduces the effectiveness of water removal and forms the larger and more elongated water droplets/slugs. The increase in compression resulted in a $34 \%$ increase in the average slug size. Increase in the slug density results in partial blocking of the channel that could lead to the non-uniform reactant distribution to the active sites on the catalyst layer [78,81,82]. Furthermore, water spreads in the channel, forming the thin water film, as highlighted in 'dashed green'. The hydrophilic channel wall fosters water adherence to the channel under the surface tension, whereas higher gas velocity across the channel $\left(0.5 \mathrm{~m} \mathrm{~s}^{-1}\right)$ results in convective water removal under higher drag forces. These two phenomena collectively result in forming the thin water film on the channel walls [82]. Increase in compression from $25 \%$ to $35 \%$ resulted in a $31 \%$ increase in the average water film thickness.

Hence, while the cell architecture and operating conditions were identical in both the compression cases and the same amount of water was being generated the given current densities, it can be concluded that the difference in the water content in the cell was solely due to the increased compression. Moreover, the radiographs of the galvanostatic operation confirmed that the voltage loss at increased compression (observed in Figure 3) was associated with increased water retention that leads to flooding and the tendency to backdiffuse water to the anode domain. 


\subsection{Effect of compression on water transport dynamics}

Effective water management, required for the optimal cell operation, can be achieved by attaining a balance between the rate of water generation due to electrochemical reaction and the rate of water removal. The radiographs presented in Figure 4 (activation region) and Figure 5 (Ohmic region) suggests that the membrane was adequately hydrated without channel flooding. However, with an increase in current density (mass transport region), the presence of liquid water in the channel suggests that the rate of water generation exceeds the rate of water removal.

Therefore, the rate of water retention influences the propensity for water flooding. The performance comparison between the cell compressions can be determined by calculating the rate of water retention within the cell $\left(\mathrm{g} \mathrm{s}^{-1}\right)$, following the increase in current density. The amount of water generation, $m_{g e n}(\mathrm{mg})$ is theoretically calculated using Faraday's law, (Equation 2)

$m_{\text {gen }}=\frac{M_{\mathrm{H}_{2} \mathrm{O} \cdot j \cdot A \cdot t}}{2 F}$

where $M_{\mathrm{H}_{2} \mathrm{O}}$ is the molecular weight of water, $A$ is the area under analysis, $j$ is the current density, and $t$ is the duration of the galvanostatic operation, which is $300 \mathrm{~s}, F$ is the Faraday constant $\left(96485 \mathrm{C} \mathrm{mol}^{-1}\right)$. The same amount of water was generated electrochemically under identical operating conditions, irrespective of the cell compression. The liquid water retention for different compressions was calculated by integrating the local water thickness across the area under analysis using (Equation 3)

$m_{r t n}=\rho_{H_{2} O} \int_{0}^{A} \delta_{w a t e r} \cdot d A$

where $\rho_{\mathrm{H}_{2} \mathrm{O}}$ is the density of the liquid water, $A$ is the area under analysis, $\delta_{\text {water }}$ is the thickness of the liquid water.

Figure 7 shows the dynamic performance, under galvanostatic operation, of water retention and cell voltage, measured at $25 \%$ and $35 \%$ compression. In the activation region, the water profile was almost invariant over the duration; however, it was influenced by compression with an increase in the compression doubling the mean water retention, which was mainly observed under the anode land region (Figure 4). The compressive effect on the anode MPL may be the reason for increased water retention, as the hydrophobic MPL resists removal of water to the anode exit. 
At $0.6 \mathrm{~A} \mathrm{~cm}^{-2}$, water retention is affected by both the compression and the duration of the galvanostatic operation. A transient water retention profile is observed with the higher compression resulting in more rapid water accumulation, before reaching a plateau above that of the $25 \%$ compression. This higher water retention of the $35 \%$ case is manifest in a reducing voltage with time, compared to a relatively stable potential profile for the $25 \%$ case.

The dynamic water retention profile in the mass transport region $\left(1 \mathrm{~A} \mathrm{~cm}^{-2}\right)$ is affected by the higher rate of water generation with the new water accumulation/retention reaching equilibrium faster than the $0.6 \mathrm{~A} \mathrm{~cm}^{-2}$ case.

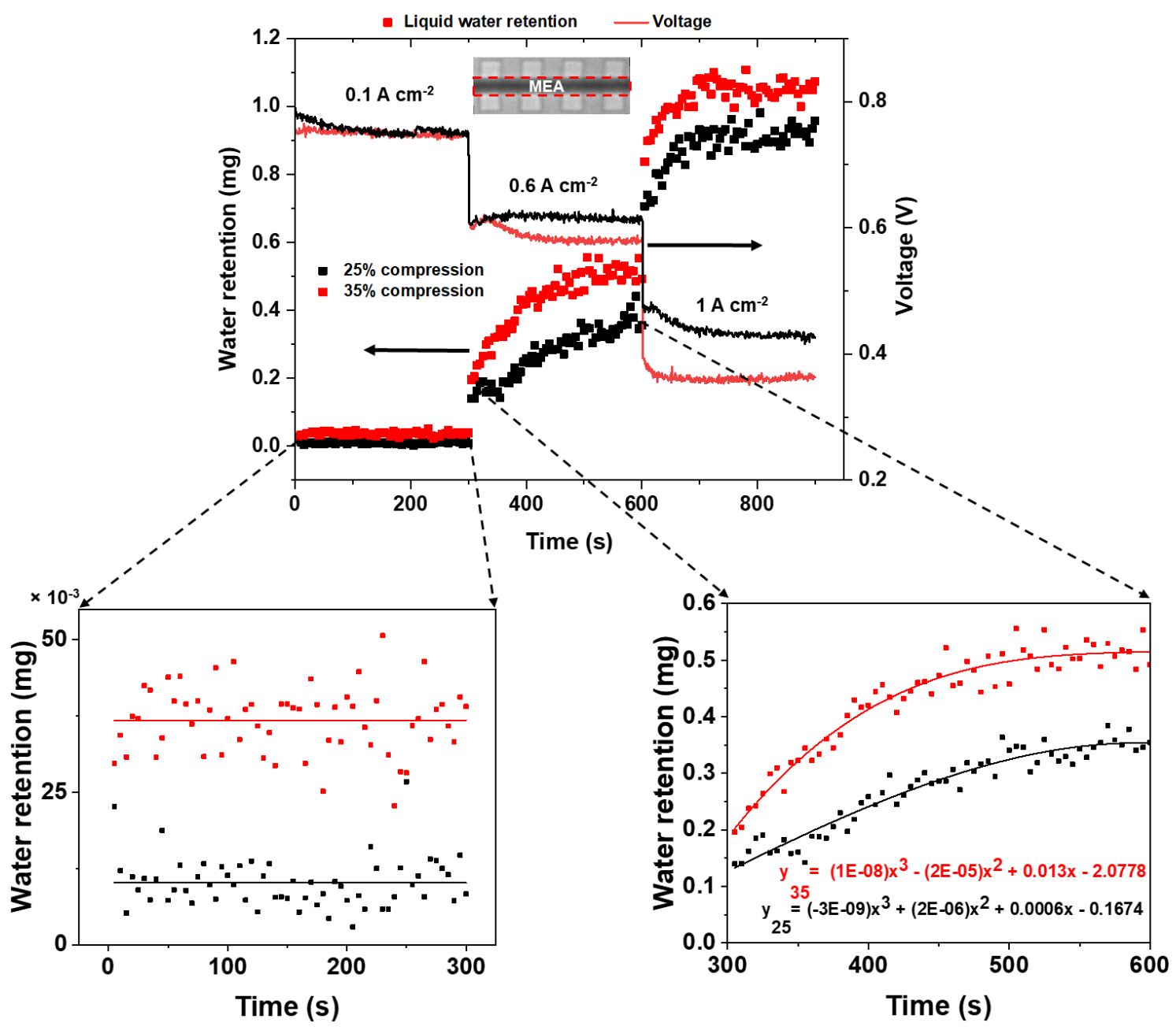

Figure 7. The dynamic effect of compression on the liquid water retention in the MEA (GDL $+C L+M e m b r a n e)$ measured from the in-plane neutron radiographs and the voltage profile during the galvanostatic operation over $300 \mathrm{~s}$.

The effectiveness of water removal is calculated as the difference between the amount of water generation and the amount of water retention. Figure 8(a) shows the effect of compression and current density on the rate of water retention and efficiency of water removal 
measured at $300 \mathrm{~s}$. Increase in the current density results in increased water generation. With fixed inlet flow conditions, the water removal efficiency was affected by the current density. Increase in current density to $j=1 \mathrm{~A} \mathrm{~cm}^{-2}$, reduced water removal efficiency by $11 \%$ and $19 \%$, for the $25 \%$ and $35 \%$ compressions, respectively. As the water removal efficiency decreases with compression, the rate of water retention in the cell increased. Increase in current density from 0.6 to $1 \mathrm{~A} \mathrm{~cm}^{-2}$, resulted in an increase in the rate of water retention by $84 \%$ and $80 \%$ when measured at $25 \%$ and $35 \%$, respectively. Moreover, cell compression affects the rate of water retention in a similar manner. The water retention in the Ohmic region $\left(j=0.6 \mathrm{~A} \mathrm{~cm}^{-}\right.$ ${ }^{2}$ ) increased by $80 \%$ with an increase in compression, and the same in the mass transport region $\left(j=1 \mathrm{~A} \mathrm{~cm}^{-2}\right)$ which increased by $88 \%$. This confirms that the compression exacerbates the effect of current density on water retention by lowering the water removal efficiency.

Increased water retention in the cell leads to the flooding conditions, as shown in previous radiographs. Active water removal mechanisms such as the electroosmotic pump effect [83], high stoichiometric open cathode PEFC designs [84], long and serpentine oxidant channels [85], anode water removal [17], etc. help to lower the effect of flooding at the cost of associated parasitic losses [3]. With no active water removal mechanism in place, like in the present cell, the generated/accumulated water under the land is either transported laterally under capillary action to the flow-channel and evacuated by the convective flux or back-diffuses to the anode (Figure 8(b)). The in-plane radiographs shown previously confirms that both the water transport mechanisms were apparent in the present case and the water content in the anode resulted from back-diffusion.

Figure 8(c) shows the characteristic effect of compression and operating load on the rate of back-diffusion plotted against the polarisation curves. The propensity of the water to backdiffuse into the anode was minimal at the low current region but increased with current density. The back-diffusion was marginally affected by compression throughout the current range with fixed flow conditions. The results presented here are in agreement with previous neutron imaging studies [44]. At identical reactant pressure and dry inlet conditions at the cathode and the anode, the net rate of water transport through the membrane is preliminarily controlled by the water concentration gradient between the anode and cathode domain and the electroosmotic drag [86,87]. Anode water thickness map presented in Figure 8(d) visually confirms that the water accumulation in the anode is in agreement with previous studies $[44,87,88]$, and was due to water back-diffusion from the cathode to the anode. However, it is important to note that the present results are provided in the central channels of the fuel cell and the effect 
of gravitational forces on the water accumulation and removal from the channel is not considered in the analysis.
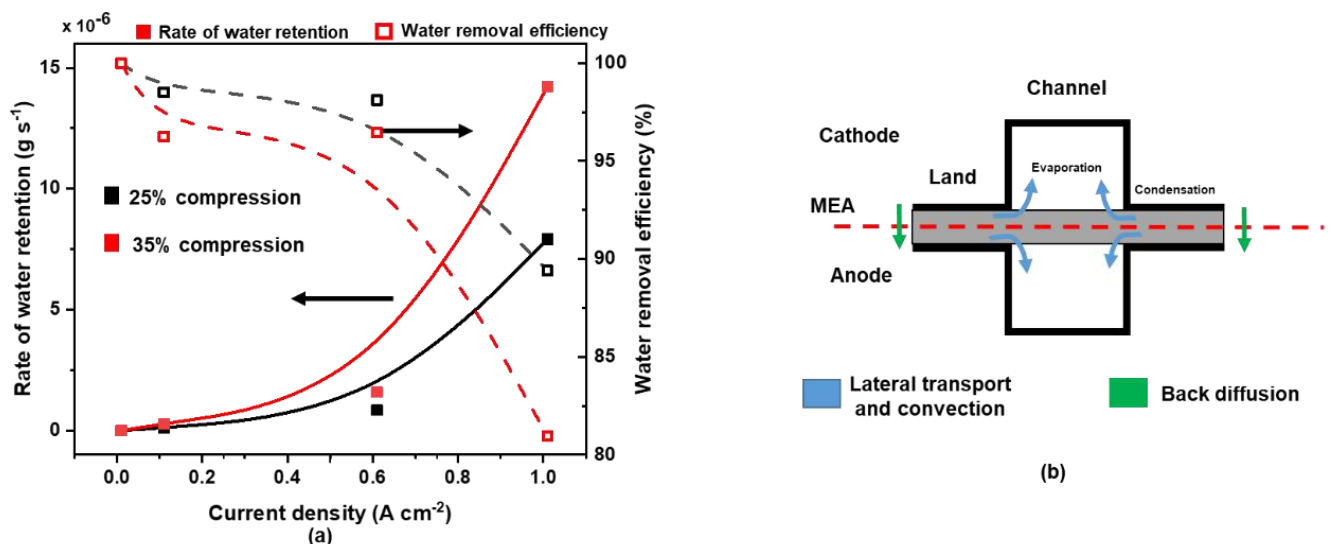

(b)
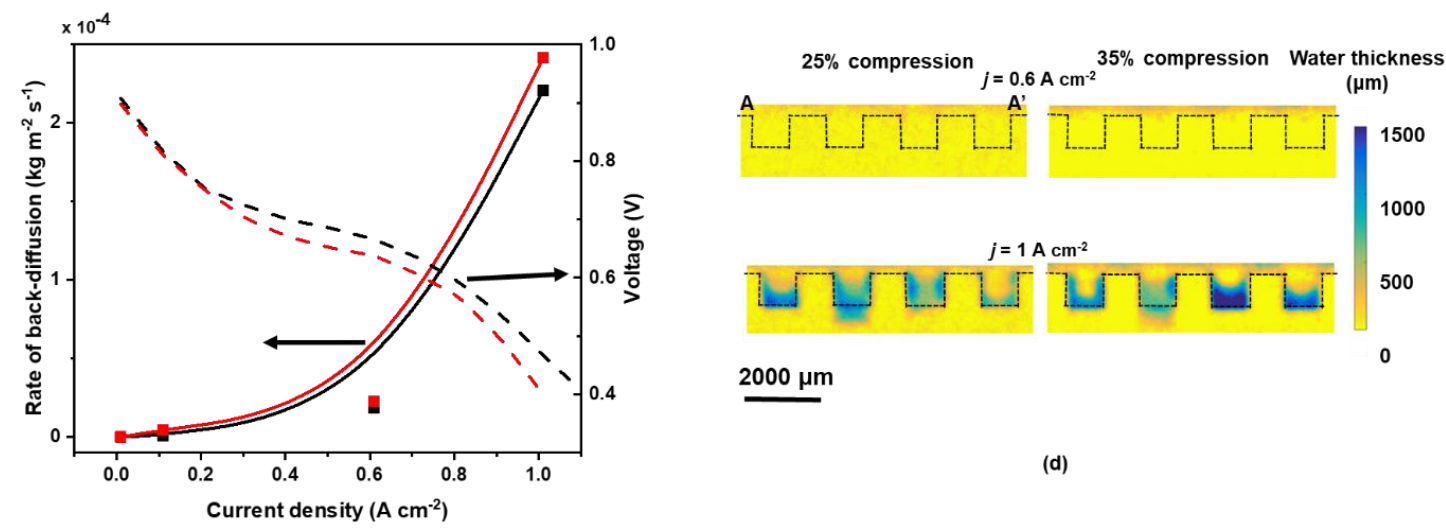

(d)

(c)

Figure 8. Effect of compression on liquid water dynamics, (a) effect of compression on the rate of water retention and water removal efficiency in the cell. B-spline passing through the data points included as a guide to the eye;

(b) schematic of the water transport in the operating fuel cell; (c) rate of back-diffusion of water through the membrane as a function of current density and cell compression; and (d) radiographs showing averaged liquid water thickness distribution in the anode domain.

\section{Conclusion}

Water distribution and accumulation have been investigated at different levels of MEA compressions for a self-humidifying PEFC using neutron imaging in both the in-plane and through-plane orientation. The in-plane radiographs showed the water distribution within the layers of the MEA highlighting the effect of land and channel pattern on the non-uniform retention of the liquid water, fluctuating between the peaks underneath lands and valleys under the channels. The through-plane radiographs provided the information about water accumulation along the channel length and across the active area of the cell, highlighting the retention profiles such as water droplets, water film and slugs. Therefore, the combined 
analysis of the in-plane and the through-plane radiographs made it possible to determine what constitutes a given 'thickness' of water mapped across the extent of an MEA.

The effect of compression on the PEFC performance and on the water transport dynamics was investigated at three operating regions of the fuel cell. Compression has a marginal effect on the cell performance and water retention at the activation region; however, the notable effect of compression on the water dynamics in the PEFC was observed in the Ohmic and the mass transport regions. Increase in compression not only resulted in an increase in mass transport dominance in the Ohmic region, promoting early mass transport losses, but also increased flooding in the mass transport region.

Under identical cell architecture and the operating conditions, the extent of water retention in the cell and water removal efficiency is principally affected by the cell compression. Increase in compression worsens the water removal efficiency of the cell and increases the back diffusion of water.

Hence, the present study effectively delineates the effect of channel/land geometry on the liquid water transport mechanism, while highlighting the strong dependence of cell compression on the water accumulation and retention in fuel cells using multi-orientation neutron radiography. Furthermore, the results presented in this study would be useful to simulation studies by providing input parameters for models used to develop advanced fuel cell stack architectures and MEAs.

\section{Acknowledgements}

The authors would like to acknowledge funding from the EPSRC (EP/L015277/1, EP/P009050/1, EP/M014371/1, EP/M009394/1, EP/M023508/1, EP/L015749/1, EP/N022971/1) for supporting fuel cell research in the Electrochemical Innovation Lab (EIL) and to the Digital Engineering and Test Centre (APC Spoke) Virtually Connected Hybrid Vehicle (VCHV) project for supporting N. Kulkarni.

\section{References}

[1] S. Litster, D. Sinton, N. Djilali, Ex situ visualization of liquid water transport in PEM fuel cell gas diffusion layers, J. Power Sources. 154 (2006) 95-105. doi:10.1016/j.jpowsour.2005.03.199.

[2] N. Djilali, Computational modelling of polymer electrolyte membrane (PEM) fuel cells: Challenges and opportunities, Energy. 32 (2007) 269-280. doi:10.1016/j.energy.2006.08.007.

[3] R. Anderson, L. Zhang, Y. Ding, M. Blanco, X. Bi, D.P. Wilkinson, A critical review of two-phase flow in gas flow channels of proton exchange membrane fuel cells, J. Power Sources. 195 (2010) 4531-4553. 
doi:10.1016/j.jpowsour.2009.12.123.

[4] F. Barbir, PEM Fuel Cells: Theory and Practice, Strateg. Manag. J. 22 (2005) 314. doi:10.1016/B978-012-387710-9.00012-6.

[5] V.B. Oliveira, C.M. Rangel, A.M.F.R. Pinto, Effect of anode and cathode flow field design on the performance of a direct methanol fuel cell, Chem. Eng. J. 157 (2010) 174-180.

doi:10.1016/j.cej.2009.11.033.

[6] D.J.L. Brett, N.P. Brandon, Review of Materials and Characterization Methods for Polymer Electrolyte Fuel Cell Flow-Field Plates, J. Fuel Cell Sci. Technol. 4 (2007) 29. doi:10.1115/1.2393303.

[7] A.D. Santamaria, P.K. Das, J.C. MacDonald, A.Z. Weber, Liquid-Water Interactions with GasDiffusion-Layer Surfaces, J. Electrochem. Soc. 161 (2014) F1184-F1193. doi:10.1149/2.0321412jes.

[8] J. Millichamp, T.J. Mason, T.P. Neville, N. Rajalakshmi, R. Jervis, P.R. Shearing, D.J.L. Brett, Mechanisms and effects of mechanical compression and dimensional change in polymer electrolyte fuel cells - A review, J. Power Sources. 284 (2015) 305-320. doi:10.1016/j.jpowsour.2015.02.111.

[9] T.J. Mason, J. Millichamp, T.P. Neville, A. El-kharouf, B.G. Pollet, D.J.L. Brett, Effect of clamping pressure on ohmic resistance and compression of gas diffusion layers for polymer electrolyte fuel cells, J. Power Sources. 219 (2012) 52-59.

https://www.sciencedirect.com/science/article/pii/S0378775312011469\#fig5 (accessed March 21, 2018).

[10] R.M. Aslam, D.B. Ingham, M.S. Ismail, K.J. Hughes, L. Ma, M. Pourkashanian, Simultaneous thermal and visual imaging of liquid water of the PEM fuel cell flow channels, J. Energy Inst. 92 (2019) 311318. doi:10.1016/J.JOEI.2018.01.005.

[11] K. Tüber, D. Pócza, C. Hebling, Visualization of water buildup in the cathode of a transparent PEM fuel cell, J. Power Sources. 124 (2003) 403-414. doi:10.1016/S0378-7753(03)00797-3.

[12] Y. Lee, B. Kim, Y. Kim, An experimental study on water transport through the membrane of a PEFC operating in the dead-end mode, Int. J. Hydrogen Energy. 34 (2009) 7768-7779. doi:10.1016/j.ijhydene.2009.07.010.

[13] A.Z. Weber, R.L. Borup, R.M. Darling, P.K. Das, T.J. Dursch, W. Gu, D. Harvey, A. Kusoglu, S. Litster, M.M. Mench, R. Mukundan, J.P. Owejan, J.G. Pharoah, M. Secanell, I. V. Zenyuk, A Critical Review of Modeling Transport Phenomena in Polymer-Electrolyte Fuel Cells, J. Electrochem. Soc. 161 (2014) F1254-F1299. doi:10.1149/2.0751412jes.

[14] B.S. Machado, N. Chakraborty, P.K. Das, Influences of flow direction, temperature and relative humidity on the performance of a representative anion exchange membrane fuel cell: A computational analysis, Int. J. Hydrogen Energy. 42 (2017) 6310-6323. doi:10.1016/j.ijhydene.2016.12.003.

[15] I. V. Zenyuk, P.K. Das, A.Z. Weber, Understanding Impacts of Catalyst-Layer Thickness on Fuel-Cell Performance via Mathematical Modeling, J. Electrochem. Soc. 163 (2016) F691-F703. doi:10.1149/2.1161607jes.

[16] T.E. Springer, T.A. Zawodzinski, S. Gottesfeld, Polymer electrolyte fuel cell model, J. Electrochem. Soc., Vol. 138, No. 8, August 1991. 138 (1993) 2334-2342.

[17] D.M. Bernardi, M.W. Verbrugge, Mathematical model of a gas diffusion electrode bonded to a polymer electrolyte, AIChE J. 37 (1991) 1151-1163. http://www.scopus.com/inward/record.url?eid=2-s2.00026204251\&partnerID=tZOtx3y1.

[18] G. He, Y. Yamazaki, A. Abudula, A three-dimensional analysis of the effect of anisotropic gas diffusion layer(GDL) thermal conductivity on the heat transfer and two-phase behavior in a proton exchange membrane fuel cell(PEMFC), J. Power Sources. 195 (2010) 1551-1560. doi:10.1016/j.jpowsour.2009.09.059.

[19] S. Mazumder, J.V. Cole, Rigorous 3-D Mathematical Modeling of PEM Fuel Cells, J. Electrochem. Soc. 150 (2003) A1510. doi:10.1149/1.1615609.

[20] L. Xing, Y. Xu, P.K. Das, B. Mao, Q. Xu, H. Su, X. Wu, W. Shi, Numerical matching of anisotropic transport processes in porous electrodes of proton exchange membrane fuel cells, Chem. Eng. Sci. 195 (2019) 127-140. doi:10.1016/J.CES.2018.11.034.

[21] L. Xing, Y. Wang, P.K. Das, K. Scott, W. Shi, Homogenization of current density of PEM fuel cells by in-plane graded distributions of platinum loading and GDL porosity, Chem. Eng. Sci. (2018). doi:10.1016/j.ces.2018.08.029.

[22] E. Carcadea, M. Varlam, D.B. Ingham, L.G. Patularu, A. Marinoiu, D. Ion-Ebrasu, I. Stefanescu, Effect of Gdl(+MPL) Compression on the PEM Fuel Cell Performance, Meet. Abstr. MA2016-02 (2016) 2742-2742. http://ma.ecsdl.org/content/MA2016-02/38/2742.

[23] J. Ihonen, F. Jaouen, G. Lindbergh, G. Sundholm, A novel polymer electrolyte fuel cell for laboratory investigations and in-situ contact resistance measurements, Electrochim. Acta. 46 (2001) 2899-2911. 
doi:10.1016/S0013-4686(01)00510-2.

[24] R. Montanini, G. Squadrito, G. Giacoppo, Measurement of the clamping pressure distribution in polymer electrolyte fuel cells using piezoresistive sensor arrays and digital image correlation techniques, J. Power Sources. 196 (2011) 8484-8493. doi:10.1016/j.jpowsour.2011.06.017.

[25] F. Alcaide, G. Alvarez, A. Querejeta, O. Miguel, I. Boyano, Effect of Gas Diffusion Layer Composition on the Performance of Liquid Direct Methanol Fuel Cells, in: ECS Trans., ECS, 2009: pp. 891-897. doi:10.1149/1.3210643.

[26] N. Kulkarni, Q. Meyer, J. Hack, R. Jervis, F. Iacoviello, K. Ronaszegi, P. Adcock, P.R. Shearing, D.J.L. Brett, Examining the effect of the secondary flow-field on polymer electrolyte fuel cells using X-ray computed radiography and computational modelling, Int. J. Hydrogen Energy. 44 (2019) 1139-1150. doi:10.1016/j.ijhydene.2018.11.038.

[27] P.K. Das, X. Li, Z.S. Liu, Analysis of liquid water transport in cathode catalyst layer of PEM fuel cells, Int. J. Hydrogen Energy. 35 (2010) 2403-2416. doi:10.1016/j.ijhydene.2009.12.160.

[28] P.K. Das, X. Li, Z.S. Liu, Effective transport coefficients in PEM fuel cell catalyst and gas diffusion layers: Beyond Bruggeman approximation, Appl. Energy. 87 (2010) 2785-2796. doi:10.1016/j.apenergy.2009.05.006.

[29] I. Nitta, T. Hottinen, O. Himanen, M. Mikkola, Inhomogeneous compression of PEMFC gas diffusion layer, J. Power Sources. 171 (2007) 26-36. doi:10.1016/j.jpowsour.2006.11.018.

[30] A.H. Mahmoudi, A. Ramiar, Q. Esmaili, Effect of inhomogeneous compression of gas diffusion layer on the performance of PEMFC with interdigitated flow field, Energy Convers. Manag. 110 (2016) 78 89. doi:10.1016/j.enconman.2015.12.012.

[31] R. Banerjee, J. Hinebaugh, H. Liu, R. Yip, N. Ge, A. Bazylak, Heterogeneous porosity distributions of polymer electrolyte membrane fuel cell gas diffusion layer materials with rib-channel compression, Int. J. Hydrogen Energy. 41 (2016) 14885-14896. doi:10.1016/j.ijhydene.2016.06.147.

[32] T. Hottinen, O. Himanen, PEMFC temperature distribution caused by inhomogeneous compression of GDL, 2007. doi:10.1016/j.elecom.2006.12.018.

[33] C. Tötzke, G. Gaiselmann, M. Osenberg, T. Arlt, H. Markötter, A. Hilger, A. Kupsch, B.R. Müller, V. Schmidt, W. Lehnert, I. Manke, Influence of hydrophobic treatment on the structure of compressed gas diffusion layers, J. Power Sources. 324 (2016) 625-636. doi:10.1016/j.jpowsour.2016.05.118.

[34] N. Kulkarni, M.D.R. Kok, R. Jervis, F. Iacoviello, Q. Meyer, P.R. Shearing, D.J.L. Brett, The effect of non-uniform compression and flow-field arrangements on membrane electrode assemblies - X-ray computed tomography characterisation and effective parameter determination, J. Power Sources. 426 (2019) 97-110. doi:10.1016/j.jpowsour.2019.04.018.

[35] R.W. Atkinson, Y. Garsany, B.D. Gould, K.E. Swider-Lyons, I. V. Zenyuk, The Role of Compressive Stress on Gas Diffusion Media Morphology and Fuel Cell Performance, ACS Appl. Energy Mater. (2017) acsaem.7b00077. doi:10.1021/acsaem.7b00077.

[36] U.U. Ince, H. Markötter, M.G. George, H. Liu, N. Ge, J. Lee, S.S. Alrwashdeh, R. Zeis, M. Messerschmidt, J. Scholta, A. Bazylak, I. Manke, Effects of compression on water distribution in gas diffusion layer materials of PEMFC in a point injection device by means of synchrotron X-ray imaging, Int. J. Hydrogen Energy. 43 (2018) 391-406. doi:10.1016/j.ijhydene.2017.11.047.

[37] T.J. Mason, J. Millichamp, T.P. Neville, P.R. Shearing, S. Simons, D.J.L. Brett, A study of the effect of water management and electrode flooding on the dimensional change of polymer electrolyte fuel cells, J. Power Sources. 242 (2013) 70-77. doi:10.1016/j.jpowsour.2013.05.045.

[38] I. Nitta, O. Himanen, M. Mikkola, Contact resistance between gas diffusion layer and catalyst layer of PEM fuel cell, 2008. doi:10.1016/j.elecom.2007.10.029.

[39] T.A. Trabold, J.P. Owejan, D.L. Jacobson, M. Arif, P.R. Huffman, In situ investigation of water transport in an operating PEM fuel cell using neutron radiography: Part 1 - Experimental method and serpentine flow field results, Int. J. Heat Mass Transf. 49 (2006) 4712-4720. doi:10.1016/j.ijheatmasstransfer.2006.07.003.

[40] A. Turhan, S. Kim, M. Hatzell, M.M. Mench, Impact of channel wall hydrophobicity on through-plane water distribution and flooding behavior in a polymer electrolyte fuel cell, Electrochim. Acta. 55 (2010) 2734-2745. doi:10.1016/j.electacta.2009.11.095.

[41] J. Kätzel, H. Markötter, T. Arlt, M. Klages, J. Haußmann, M. Messerschmidt, N. Kardjilov, J. Scholta, J. Banhart, I. Manke, Effect of ageing of gas diffusion layers on the water distribution in flow field channels of polymer electrolyte membrane fuel cells, J. Power Sources. 301 (2016) 386-391. doi:10.1016/j.jpowsour.2015.10.004.

[42] S. Gößling, M. Klages, J. Haußmann, P. Beckhaus, M. Messerschmidt, T. Arlt, N. Kardjilov, I. Manke, J. Scholta, A. Heinzel, Analysis of liquid water formation in polymer electrolyte membrane (PEM) fuel 
cell flow fields with a dry cathode supply, J. Power Sources. 306 (2016) 658-665.

doi:10.1016/j.jpowsour.2015.12.060.

[43] H. Markötter, I. Manke, R. Kuhn, T. Arlt, N. Kardjilov, M.P. Hentschel, A. Kupsch, A. Lange, C. Hartnig, J. Scholta, J. Banhart, Neutron tomographic investigations of water distributions in polymer electrolyte membrane fuel cell stacks, J. Power Sources. 219 (2012) 120-125.

doi:10.1016/j.jpowsour.2012.07.043.

[44] A. Iranzo, P. Boillat, Liquid water distribution patterns featuring back-diffusion transport in a PEM fuel cell with neutron imaging, Int. J. Hydrogen Energy. 39 (2014) 17240-17245.

doi:10.1016/j.ijhydene.2014.08.042.

[45] A. Iranzo, A. Salva, P. Boillat, J. Biesdorf, E. Tapia, F. Rosa, Water build-up and evolution during the start-up of a PEMFC: Visualization by means of Neutron Imaging, Int. J. Hydrogen Energy. 42 (2017) 13839-13849. doi:10.1016/j.ijhydene.2016.11.076.

[46] J.B. Siegel, S. V. Bohac, A.G. Stefanopoulou, S. Yesilyurt, Nitrogen front evolution in purged polymer electrolyte membrane fuel cell with dead-ended anode, J. Electrochem. Soc. 157 (2010) B1081. doi:10.1149/1.3425743.

[47] P. Stahl, J. Biesdorf, P. Boillat, J. Kraft, K. a. Friedrich, Water Distribution Analysis in the Outer Perimeter Region of Technical PEFC Based on Neutron Radiography, J. Electrochem. Soc. 162 (2015) F677-F685. doi:10.1149/2.0351507jes.

[48] N. Kardjilov, A. Hilger, I. Manke, CONRAD-2: Cold Neutron Tomography and Radiography at BER II (V7), J. Large-Scale Res. Facil. JLSRF. 2 (2016) 98. doi:10.17815/jlsrf-2-108.

[49] C. Tötzke, I. Manke, A. Hilger, G. Choinka, N. Kardjilov, T. Arlt, H. Markötter, A. Schröder, K. Wippermann, D. Stolten, C. Hartnig, P. Krüger, R. Kuhn, J. Banhart, Large area high resolution neutron imaging detector for fuel cell research, J. Power Sources. 196 (2011) 4631-4637. doi:10.1016/j.jpowsour.2011.01.049.

[50] N. Kardjilov, I. Manke, R. Woracek, A. Hilger, J. Banhart, Advances in neutron imaging, Mater. Today. 21 (2018) 652-672. doi:10.1016/j.mattod.2018.03.001.

[51] A. Bazylak, Liquid water visualization in PEM fuel cells: A review, Int. J. Hydrogen Energy. 34 (2009) 3845-3857. doi:10.1016/j.ijhydene.2009.02.084.

[52] N. Kardjilov, A. Hilger, I. Manke, R. Woracek, J. Banhart, CONRAD-2: the new neutron imaging instrument at the Helmholtz-Zentrum Berlin, J. Appl. Crystallogr. 49 (2016) 195-202. doi:10.1107/s1600576715023353.

[53] Q. Meyer, S. Ashton, P. Boillat, M. Cochet, E. Engebretsen, D.P. Finegan, X. Lu, J.J. Bailey, N. Mansor, R. Abdulaziz, O.O. Taiwo, R. Jervis, S. Torija, P. Benson, S. Foster, P. Adcock, P.R. Shearing, D.J.L. Brett, Effect of gas diffusion layer properties on water distribution across air-cooled, opencathode polymer electrolyte fuel cells: A combined ex-situ X-ray tomography and in-operando neutron imaging study, Electrochim. Acta. 211 (2016) 478-487. doi:10.1016/j.electacta.2016.06.068.

[54] P. Boillat, D. Kramer, B.C. Seyfang, G. Frei, E. Lehmann, G.G. Scherer, A. Wokaun, Y. Ichikawa, Y. Tasaki, K. Shinohara, In situ observation of the water distribution across a PEFC using high resolution neutron radiography, Electrochem. Commun. 10 (2008) 546-550. doi:10.1016/j.elecom.2008.01.018.

[55] A. Iranzo, P. Boillat, P. Oberholzer, J. Guerra, A novel approach coupling neutron imaging and numerical modelling for the analysis of the impact of water on fuel cell performance, Energy. 68 (2014) 971-981. doi:10.1016/j.energy.2014.03.014.

[56] A. Iranzo, M. Muñoz, J. Pino, F. Rosa, Update on numerical model for the performance prediction of a PEM Fuel Cell, Int. J. Hydrogen Energy. 36 (2011) 9123-9127. doi:10.1016/j.ijhydene.2011.04.102.

[57] J.I.S. Cho, T.P. Neville, P. Trogadas, Q. Meyer, Y. Wu, R. Ziesche, P. Boillat, M. Cochet, V. ManziOrezzoli, P. Shearing, D.J.L. Brett, M.-O. Coppens, Visualization of liquid water in a lung-inspired flow-field based polymer electrolyte membrane fuel cell via neutron radiography, Energy. 170 (2019) 14-21. doi:10.1016/j.energy.2018.12.143.

[58] Y. Wu, J.I.S. Cho, T.P. Neville, Q. Meyer, R. Ziesche, P. Boillat, M. Cochet, P.R. Shearing, D.J.L. Brett, Effect of serpentine flow-field design on the water management of polymer electrolyte fuel cells: An in-operando neutron radiography study, J. Power Sources. 399 (2018) 254-263. doi:10.1016/j.jpowsour.2018.07.085.

[59] Y. Wu, J.I.S. Cho, X. Lu, L. Rasha, T.P. Neville, J. Millichamp, R. Ziesche, N. Kardjilov, H. Markötter, P. Shearing, D.J.L. Brett, Effect of compression on the water management of polymer electrolyte fuel cells: An in-operando neutron radiography study, J. Power Sources. 412 (2019) 597-605. doi:10.1016/j.jpowsour.2018.11.048.

[60] H. Liu, P. Li, D. Juarez-Robles, K. Wang, A. Hernandez-Guerrero, Experimental Study and Comparison of Various Designs of Gas Flow Fields to PEM Fuel Cells and Cell Stack Performance, Front. Energy 
Res. 2 (2014) 1-8. doi:10.3389/fenrg.2014.00002.

[61] H. Liu, P. Li, J. Van Lew, CFD study on flow distribution uniformity in fuel distributors having multiple structural bifurcations of flow channels, Int. J. Hydrogen Energy. 35 (2010) 9186-9198. doi:10.1016/j.ijhydene.2010.06.043.

[62] Q. Meyer, N. Mansor, F. Iacoviello, P.L. Cullen, R. Jervis, D. Finegan, C. Tan, J. Bailey, P.R. Shearing, D.J.L. Brett, Investigation of Hot Pressed Polymer Electrolyte Fuel Cell Assemblies via X-ray Computed Tomography, Electrochim. Acta. 242 (2017) 125-136. doi:10.1016/j.electacta.2017.05.028.

[63] J. Ge, A. Higier, H. Liu, Effect of gas diffusion layer compression on PEM fuel cell performance, J. Power Sources. 159 (2006) 922-927. doi:10.1016/j.jpowsour.2005.11.069.

[64] M. Mehrtash, I. Tari, S. Yesilyurt, Impacts of inhomogeneous clamping force on local performance and liquid water formation in polymer electrolyte fuel cells, Int. J. Hydrogen Energy. 42 (2017) 1922719245. doi:10.1016/j.ijhydene.2017.06.139.

[65] D. Muirhead, R. Banerjee, M.G. George, N. Ge, P. Shrestha, H. Liu, J. Lee, A. Bazylak, Liquid water saturation and oxygen transport resistance in polymer electrolyte membrane fuel cell gas diffusion layers, Electrochim. Acta. 274 (2018) 250-265. doi:10.1016/j.electacta.2018.04.050.

[66] S. Chevalier, J. Lee, N. Ge, R. Yip, P. Antonacci, Y. Tabuchi, T. Kotaka, A. Bazylak, In operando measurements of liquid water saturation distributions and effective diffusivities of polymer electrolyte membrane fuel cell gas diffusion layers, Electrochim. Acta. 210 (2016) 792-803. doi:10.1016/j.electacta.2016.05.180.

[67] J. Lee, S. Chevalier, R. Banerjee, P. Antonacci, N. Ge, R. Yip, T. Kotaka, Y. Tabuchi, A. Bazylak, Investigating the effects of gas diffusion layer substrate thickness on polymer electrolyte membrane fuel cell performance via synchrotron X-ray radiography, Electrochim. Acta. 236 (2017) 161-170. doi:10.1016/j.electacta.2017.03.162.

[68] C. Hartnig, I. Manke, N. Kardjilov, A. Hilger, M. Grünerbel, J. Kaczerowski, J. Banhart, W. Lehnert, Combined neutron radiography and locally resolved current density measurements of operating PEM fuel cells, J. Power Sources. 176 (2008) 452-459. doi:10.1016/j.jpowsour.2007.08.058.

[69] T. Hottinen, O. Himanen, S. Karvonen, I. Nitta, Inhomogeneous compression of PEMFC gas diffusion layer, J. Power Sources. 171 (2007) 113-121. doi:10.1016/j.jpowsour.2006.10.076.

[70] M. Klages, S. Enz, H. Markötter, I. Manke, N. Kardjilov, J. Scholta, Investigations on dynamic water transport characteristics in flow field channels using neutron imaging techniques, J. Power Sources. 239 (2013) 596-603. doi:10.1016/j.jpowsour.2013.01.196.

[71] D. Muirhead, R. Banerjee, J. Lee, M.G. George, N. Ge, H. Liu, S. Chevalier, J. Hinebaugh, K. Han, A. Bazylak, Simultaneous characterization of oxygen transport resistance and spatially resolved liquid water saturation at high-current density of polymer electrolyte membrane fuel cells with varied cathode relative humidity, Int. J. Hydrogen Energy. 42 (2017) 29472-29483. doi:10.1016/j.ijhydene.2017.10.031.

[72] S. Chaudhary, V.K. Sachan, P.K. Bhattacharya, Two dimensional modelling of water uptake in proton exchange membrane fuel cell, Int. J. Hydrogen Energy. 39 (2014) 17802-17818. doi:10.1016/j.ijhydene.2014.08.128.

[73] J.M. LaManna, S. Chakraborty, J.J. Gagliardo, M.M. Mench, Isolation of transport mechanisms in PEFCs using high resolution neutron imaging, Int. J. Hydrogen Energy. 39 (2014) 3387-3396. doi:10.1016/j.ijhydene.2013.12.021.

[74] L. Xing, M. Mamlouk, K. Scott, A two dimensional agglomerate model for a proton exchange membrane fuel cell, Energy. 61 (2013) 196-210. doi:10.1016/j.energy.2013.08.026.

[75] P.K. Das, A. Grippin, A. Kwong, A.Z. Weber, Liquid-Water-Droplet Adhesion-Force Measurements on Fresh and Aged Fuel-Cell Gas-Diffusion Layers, J. Electrochem. Soc. 159 (2012) B489-B496. doi:10.1149/2.052205jes.

[76] J.I.S. Cho, T.P. Neville, P. Trogadas, J. Bailey, P. Shearing, D.J.L. Brett, M.-O. Coppens, Capillaries for water management in polymer electrolyte membrane fuel cells, Int. J. Hydrogen Energy. 43 (2018) 21949-21958. doi:10.1016/j.ijhydene.2018.10.030.

[77] Q. Meyer, S. Ashton, O. Curnick, T. Reisch, P. Adcock, K. Ronaszegi, J.B. Robinson, D.J.L. Brett, Dead-ended anode polymer electrolyte fuel cell stack operation investigated using electrochemical impedance spectroscopy, off-gas analysis and thermal imaging, J. Power Sources. 254 (2014) 1-9. doi:10.1016/j.jpowsour.2013.11.125.

[78] T. Hellstern, E. Gauthier, M.J. Cheah, J.B. Benziger, The role of the gas diffusion layer on slug formation in gas flow channels of fuel cells, Int. J. Hydrogen Energy. 38 (2013) 15414-15427. doi:10.1016/j.ijhydene.2013.09.073.

[79] D. Lorenzini-Gutierrez, S.G. Kandlikar, A. Hernandez-Guerrero, F. Elizalde-Blancas, Residence time of 
water film and slug flow features in fuel cell gas channels and their effect on instantaneous area coverage ratio, J. Power Sources. 279 (2015) 567-580. doi:10.1016/j.jpowsour.2015.01.041.

[80] S.-H. Ge, B.-L. Yi, A mathematical model for PEMFC in different flow modes, J. Power Sources. 124 (2003) 1-11. doi:10.1016/S0378-7753(03)00584-6.

[81] T. Ous, C. Arcoumanis, Visualisation of water accumulation in the flow channels of PEMFC under various operating conditions, J. Power Sources. 187 (2009) 182-189.

doi:10.1016/j.jpowsour.2008.10.072.

[82] Z. Lu, C. Rath, G. Zhang, S.G. Kandlikar, Water management studies in PEM fuel cells, part IV: Effects of channel surface wettability, geometry and orientation on the two-phase flow in parallel gas channels, Int. J. Hydrogen Energy. 36 (2011) 9864-9875. doi:10.1016/j.ijhydene.2011.04.226.

[83] C.R. Buie, J.D. Posner, T. Fabian, S.-W. Cha, D. Kim, F.B. Prinz, J.K. Eaton, J.G. Santiago, Water management in proton exchange membrane fuel cells using integrated electroosmotic pumping, J. Power Sources. 161 (2006) 191-202. doi:10.1016/J.JPOWSOUR.2006.03.021.

[84] Q. Meyer, K. Ronaszegi, J.B. Robinson, M. Noorkami, O. Curnick, S. Ashton, A. Danelyan, T. Reisch, P. Adcock, R. Kraume, P.R. Shearing, D.J.L. Brett, Combined current and temperature mapping in an air-cooled, open-cathode polymer electrolyte fuel cell under steady-state and dynamic conditions, J. Power Sources. 297 (2015) 315-322. doi:10.1016/j.jpowsour.2015.07.069.

[85] S. Shahsavari, A. Desouza, M. Bahrami, E. Kjeang, Thermal analysis of air-cooled PEM fuel cells, Int. J. Hydrogen Energy. 37 (2012) 18261-18271. doi:10.1016/j.ijhydene.2012.09.075.

[86] D.J.L. Brett, S. Atkins, N.P. Brandon, N. Vasileiadis, V. Vesovic, A.R. Kucernak, Membrane resistance and current distribution measurements under various operating conditions in a polymer electrolyte fuel cell, J. Power Sources. 172 (2007) 2-13. doi:10.1016/j.jpowsour.2007.05.071.

[87] F. Liu, G. Lu, C. Wang, Water transport coefficient distribution through the membrane in a polymer electrolyte fuel cell, J. Memb. Sci. 287 (2007) 126-131. doi:10.1016/j.memsci.2006.10.030.

[88] V.N. Duy, J. Lee, K. Kim, J. Ahn, S. Park, T. Kim, H.M. Kim, Dynamic simulations of under-rib convection-driven flow-field configurations and comparison with experiment in polymer electrolyte membrane fuel cells, J. Power Sources. 293 (2015) 447-457. doi:10.1016/j.jpowsour.2015.05.107. 